\title{
Article
}

\section{Does Risk Disclosure Matter for Trade Credit?}

\author{
Issal Haj-Salem ${ }^{1}$ iD and Khaled Hussainey ${ }^{2, * \mathbb{D}}$ \\ 1 Department of Accounting, Institute of Higher Commercial Studies of Carthage, University of Carthage, \\ Carthage 1054, Tunisia; issal.hajsalem@gmail.com \\ 2 Accounting and Financial Management Group, Faculty of Business and Law, University of Portsmouth, \\ Portsmouth PO1 3DE, UK \\ * Correspondence: Khaled.Hussainey@port.ac.uk; Tel.: +44-239-2844-715
}

check for updates

Citation: Haj-Salem, Issal, and Khaled Hussainey. 2021. Does Risk Disclosure Matter for Trade Credit? Journal of Risk and Financial Management 14: 133.

https://doi.org/10.3390/jrfm14030133

Academic Editor: George Halkos

Received: 16 February 2021

Accepted: 17 March 2021

Published: 20 March 2021

Publisher's Note: MDPI stays neutral with regard to jurisdictional claims in published maps and institutional affiliations.

Copyright: (c) 2021 by the authors. Licensee MDPI, Basel, Switzerland. This article is an open access article distributed under the terms and conditions of the Creative Commons Attribution (CC BY) license (https:// creativecommons.org/licenses/by/ $4.0 /)$.

\begin{abstract}
In this paper, we examine the impact of risk disclosure practices on trade credit. We hypothesize that risk information could reduce information opacity that arises between companies and their suppliers. We collected annual reports for Tunisian listed companies for the period 20082013. This gives us 146 firm-year observations. We find that risk disclosure has a positive impact on the level of trade credit. Our paper offers a new empirical evidence on the role of risk disclosure in reducing information asymmetry and increase companies' access to short-term external funds. Our study provides managerial implications for firms, suppliers, and regulatory authorities.
\end{abstract}

Keywords: risk disclosure; trade credit; content analysis; Tunisian listed companies

\section{Introduction}

Access to finance is a challenge for companies worldwide to preserve and enhance their growth. This was also considered a major problem for emerging companies (Brown et al. 2011) and particularly for African ones (Fowowe 2017). Many African countries have witnessed many financial reforms (e.g., financial regulatory framework, monetary policy framework, supervisory framework, etc.) over the last three decades to overcome a long period of weak performance (Banya and Biekpe 2017). Debt financing and trade credit used to be the two main sources of financing. Nevertheless, the first refers to loans provided by financial institutions and the latter refers to loans provided by suppliers for a short period when firms purchase their products ( $X u$ et al. 2020). Researchers believe that using trade credit may help firms to access bank loans since it is considered a good signal (Andrieu et al. 2017). Moreover, firms are likely to use trade credit rather than bank credit during a tight money period ( $\mathrm{Xu}$ et al. 2020). In this context, in Tunisia, the Arab spring undoubtedly mitigates bank credit availability for Tunisian firms. Many reforms took place to improve the financial soundness indicators and financial stability. The restrictive monetary policy conducted by the Tunisian Central Bank (BCT) since 2017 with five increases in the interest rate had a considerable effect on the evolution of loans to the economy which severely decreased to reach $+4.9 \%$ in August 2019 against $+5.7 \%$ in July and $+10.9 \%$ in August 2018. Furthermore, to protect banks against excessive risk-taking, the BCT, through circular $\mathrm{n}^{\circ} 2018-10$ of 1 November 2018, instituted a new credit/deposit ratio. This was a restriction likely to rationalize the granting of loans since Tunisian banks must not exceed the limit of $120 \%$ for this latter. Consequently, a clear slowdown in the pace of credit evolution has been established. Accordingly, firms are likely to search for other financing sources. For that, the trade-credit was considered one of the most important short-term financing sources.

Although the important role of trade credit as one of the most important sources of the short-term financing, the association between corporate risk disclosure and trade credit remains largely unexplored. Recently, there are only a few researchers, such as (Xu et al. 2020) and Ceustermans et al. (2017) that have started to examine, respectively, 
the impact of the readability of annual reports on trade credit; and the impact of corporate voluntary disclosure on trade credit for small private firms.

The objective of our paper is to examine the impact of risk disclosure on trade credit. We aim to answer to the following research question "Does risk disclosure matter for trade credit? To achieve our research objective, we measured levels of risk disclosure for a sample of Tunisian listed firms during 2008-2013 and manually collected accounting information from corporate annual reports. We find that risk disclosure determines the trade credit provided by suppliers to their customers. Indeed, risk disclosure mitigates information asymmetry which leads to a positive association with the obtained trade credit. Moreover, risk disclosure sends signals to suppliers helping them to assess adequately the firm risk situation and to avoid any misinterpretation or to imagine the worst situation. This helps suppliers to extend more trade credit. Our results are robust after using, on the one hand, a $\log$ transformation and, on the other hand, another measure of trade credit.

Our paper offers interesting contributions to disclosure literature. We focus on the Tunisian context, as an example of an emerging market during a period of crisis. Moreover, we contribute to the economic consequences of risk disclosure literature by examining its impact on trade credit, which has received a considerable attention since the global financial crisis. To the best of our knowledge, no study, to date, has examined the impact of risk disclosure practices on trade credit.

The rest of the paper is organized as follows. In Section 2, we review the literature and develop our research hypothesis. In Section 3, we discuss the research method (sample, research model, and variables' measurement). In Section 4, we present and discuss our findings. Section 5 concludes the paper.

\section{Literature Review and Hypothesis Development}

\subsection{Motivations of Trade Credit}

Trade credit appears when firms have differed payment of sales or purchases. Overall, the payment period is about 30 days and it could be extended according to the arrangement between customers and suppliers. Trade credit is omnipresent in different industries and economies (Islam and Wheatley 2020). It was considered the second most important source of short-term financing behind bank financing as well for developed countries or developing countries (Fisman 2001). Moreover, prior researchers state that trade credit is most used in developing countries, where credit from financial institutions is limited (Giannetti et al. 2011). Many empirical studies find that trade credit could be a substitute for bank loans particularly in the early stage and then it could become its complement (Huyghebaert et al. 2007).

The motivations of trade credit could be classified into financial, operational/transaction, and commercial ones. Firstly, according to the financing theory market imperfections lead to limited credit accessibility for several firms (Schwartz 1974). Also, suppliers are likely to extend credit to their customers at lower costs than their financial institutions due to information asymmetry for the latter (Petersen and Rajan 1997). Secondly, according to commercial theories extending trade credit may build a long-term relationship and reinforce the loyalty of customers to the firms' products (Cheng and Pike 2003), or even expand their markets by attracting new customers (Van Horen 2005). Moreover, the trade credit could be used as a quality guarantee to allow customers verifying products' quality before the pay for these products. In addition, it could be used by suppliers as a signal for the quality of their goods (Long et al. 1993; Smith 1987).

\subsection{Risk Disclosure Literature}

Corporate risk disclosure (CRD) is one of the hottest research areas as it offers managerial and policy/regulatory implications. The first studies on risk disclosure have been conducted to understand the attitudes of stakeholders and the relevance of such practice for their decision-making (e.g., Deumes 2008; Solomon et al. 2000) and its usefulness to investors since it alleviates the information asymmetry (Miihkinen 2013). Furthermore, 
many studies were conducted to investigate the determinants of risk disclosure rather than its relevance. Those studies consider corporate governance mechanisms and firm characteristics as potential drivers for corporate risk disclosure. Through prior studies, we find that studies in developing countries (Al-Maghzom et al. 2016; Alzead and Hussainey 2017) are scarce compared to developed ones (Abraham and Cox 2007; Beretta and Bozzolan 2004; Elshandidy et al. 2013; Elshandidy and Shrives 2016; Elzahar and Hussainey 2012; Linsley et al. 2006; Miihkinen 2012, 2013). Prior empirical studies (Al-Maghzom et al. 2016; Alkurdi et al. 2019; Allini et al. 2015; Alzead and Hussainey 2017; Bufarwa et al. 2020; Elshandidy and Neri 2015; Haj-Salem et al. 2019; Nahar et al. 2020) have been mainly focused on the determinants of risk disclosure such as corporate governance attributes (board size, independent directors, CEO duality, ownership structure, audit quality, etc.) and firm-specific characteristics (firm size, growth, industry type, etc.). Moreover, the economic consequences of the risk disclosure practices start being investigated (Haj-Salem et al. 2020). In our paper, we are wondering whether the risk disclosure may enhance or hinders suppliers to extend trade credit as it is one of the most important sources of short-term financing. No study has investigated this issue, to the best of the authors' knowledge. Recently, few researchers start investigating the association between trade credit and disclosure in general and particularly annual report readability (Xu et al. 2020) or voluntary disclosure (Ceustermans et al. 2017). For instance, Ceustermans et al. (2017) found that voluntary disclosure is positively related to the level of trade credit for small and private companies. They argued, that providing more financial information mitigates traditional information asymmetry between firms and their creditors. Consequently, trade creditors are likely to react louder than banks to voluntary disclosure since they do not ask usually for private information from their customers to keep their trust relationship. In the same vein, the results of $\mathrm{Xu}$ et al. (2020) indicate that firms with more readable annual reports are likely to benefit from more trade credit.

Since empirical research linking risk disclosure with trade credit has not been yet undertaken despite the importance to understand this association, our study aims to fill this void in the literature and we expect that risk disclosure practices influence creditors' behaviors.

\subsection{Hypothesis Development}

The agency theory shows that, there is information asymmetry between principals and agent (Fama and Jensen 1983; Jensen and Meckling 1976). Accordingly, the agent (the firm) tries to undertake several ways to mitigate the information asymmetry with the principals (stakeholders). For that, prior studies considered risk disclosure as a mean to alleviate this information opacity with stakeholders, since it enables the latter to estimate the firm risk profile. Moreover, overall companies disclose risks and the way to manage them. This information will be relevant for different stakeholders (investors, creditors, etc.) before making financial decisions (Haj-Salem et al. 2020). Accordingly, risk disclosure could have a positive impact the level of trade credit. Moreover, based on signaling theory, the risk disclosure could be considered as a signal for suppliers and tend to mitigate the information asymmetry. This signal may enhance the company's reputation and its market valuation (Al-Maghzom et al. 2016). Indeed, a higher information asymmetry is likely to increase the risk of customers' payment default. Consequently, suppliers may hinder granting trade credit (Ceustermans et al. 2017). Furthermore, suppliers rely more on available information rather than asking for sensitive information from their customers since this may destroy their trust relationship (Arruñada 2010). Accordingly, to overcome any misinterpretation suppliers need more risk information to better assess the firm situation, otherwise, they will consider it as withholding the worst possible information (Spence 1973) which will refrain from lending decisions. Prior researchers indicate that companies using more trade credit are more likely to provide financial statements (Yohn and Allee 2009). Moreover, others predict a positive association between disclosure and a firm's dependence on external finance (Diamond and Verrecchia 1991). Recently, Ceustermans et al. (2017) find that 
voluntary disclosure mitigates information asymmetry and consequently there is a positive association between disclosure in financial statements and the ability to receive more trade credit. Furthermore, the empirical findings of Xu et al. (2020) indicate that suppliers are likely to grant more trade credit to customers with more readable annual reports. We therefore hypothesize that:

Risk disclosure positively affects the level of trade credit.

\section{Research Method}

\subsection{Our Sample}

Our sampling process started by collecting annual reports of non-financial listed companies from the BVMT (Tunisian Stock Exchange) for the period 2008-2013.

In line with prior research (Haj-Salem et al. 2020), we excluded financial companies because of their specific requirements and regulation for risk disclosure. Our initial sample involves 28 Tunisian listed firms which represent approximately 90 percent of all nonfinancial Tunisian listed companies. We manually collect our data from corporate annual reports and CMF (Financial Market Council). We focused on annual reports since there were considered as the primary mean of information for stakeholders (Marston and Shrives 1991; Miihkinen 2013).

We checked the existence of outliers to avoid bias in our findings. This is in line with prior literature. For that, using a Student's t-test helps us to remove all observations with a $t$ greater than 2 in absolute value (Fox 2015). This gives us a final sample of 146 firm-years observations.

We choose Tunisia as a context for our study for many reasons. Tunisia is an emerging market, and recently there are several calls for more research on CRD in developing countries (Khlif and Hussainey 2016). Moreover, during constraint's periods, firms are more vulnerable to financing, and the dependence on bank financing and trade credit increases ( Lin and Qiao 2020). Furthermore, firms usually suffer from bank credit-granting during the crisis and tend to use more trade credit (Chen et al. 2019). For that, suppliers were considered as viable financing sources during the global financial crisis (Bazzana et al. 2019) and play an important role in the survival of Small to Medium Enterprise (SMEs) during the crisis (Pattnaik et al. 2020). Accordingly, it is interesting to investigate the association between risk disclosure and trade credit in the Tunisian context during 2008-2013, since it was a period characterized by economic and political instability. It is important to highlight that the year 2014 was characterized by a political transition in Tunisia, which was the legislative and presidential elections that were considered an official beginning for a democratic transition. This new political system may undoubtedly impact the socioeconomic situation of the country. For that, our sample period ends on 2013. Table 1 provides a description of our sample by industry.

Table 1. Sample description.

\begin{tabular}{cc}
\hline Industry & Firms Numbers \\
\hline Telecommunications & 2 \\
Consumer services & 5 \\
Health & 2 \\
Consumer goods & 8 \\
Industrials & 7 \\
Basic Material & 3 \\
Oil and Gas & 1 \\
TOTAL & 28 \\
Original sample & 168 \\
(-) Missing reports & 13 \\
(-) Outliers & 9 \\
Final sample & 146 \\
\hline
\end{tabular}




\subsection{Measuring Trade Credit}

The dependent variable in our study is trade credit (TC). According to prior works (e.g., Deloof and La Rocca 2015) there are several measures that could be used. For instance, the accounts payable over total assets are used to take into account trade credit demand. Moreover, in order to reflect the supply of trade credit the accounts receivables over total assets is more suitable. In addition, we could measure the net trade credit by the differences of the two latter proxies. Furthermore, other researchers (e.g., Chen et al. 2019) used the sum of customer deposits, accounts payable and notes payable, divided by the cost of goods sold. For our study, and following prior research (e.g., Ceustermans et al. 2017; Chen et al. 2017; Islam and Wheatley 2020; Petersen and Rajan 1997; Xu et al. 2020), we measure the trade credit as the ratio of accounts payable to total assets as shown on the balance sheet.

\subsection{Measuring the Risk Disclosure}

We use the content analysis method to measure risk disclosure levels in Tunisian annual reports. We refer to the definition of risk disclosure as advanced by (Linsley et al. 2006) as "any opportunity or prospect, or of any hazard, danger, harm, threat or exposure, that has already impacted upon the company or may impact upon the company in the future or of the management of any such opportunity, prospect, hazard, harm, or threat or exposure". Following prior research (Al-Shammari 2014; Amran et al. 2008; Beretta and Bozzolan 2004) we use "sentence" as the unit of our textual analysis. We also use a disclosure index adapted to the Tunisian context, developed by Haj-Salem et al. (2020). This index is composed of 48 items and it was inspired by Linsley et al. (2006) and Moumen et al. (2015) ("Appendix A").

We use the stability, reproducibility, and accuracy tests to check the reliability of our risk disclosure measure Krippendorff (2004). For that, five annual reports were independently coded by the coder at different times. Moreover, another coder used the same index to code the same annual reports. After comparing results using the "ReCal" online statistical software the results present a satisfactory level of inter-coder reliability.

\subsection{Our Control Variables}

Our regression model includes a number of control variables. Consistent with prior literature, we control for firm age measured by calculating the natural logarithm of the number of years since the incorporation of the company ( $X u$ et al. 2020). There is no consensus about the impact of firm age on trade credit. Some researchers find that there is a negative association between trade credit and firm age (Chen et al. 2017). Nevertheless, others believe that the use of trade credit is more important in older firms (Petersen and Rajan 1997). In our study, we expect a negative impact of firm age on trade credit since younger firms are likely to have difficulty, comparing to older ones, obtaining bank loans. Accordingly, they rely more on trade credit as a source of short-term finance (Deloof and La Rocca 2015).

We control for firm size measured by calculating the natural logarithm of total assets. Larger firms are considered more creditworthy. They are more likely to have access easily to trade credit thanks to their negotiation power with suppliers (Ceustermans et al. 2017).

We also control for profitability measured by market to book value. This is consistent with prior works on trade credit (Xu et al. 2020). We expect a negative coefficient since firms with higher profitability may easier have more financing from other sources because they have less default risk than less profitable firms. Accordingly, they will use less trade credit (Chen et al. 2017; García-Teruel and Martínez-Solano 2007; Petersen and Rajan 1997).

We control for solvency. We use equity divided by total assets as a measure for solvency (Ceustermans et al. 2017). We also control for liquidity measured by the calculation of the ratio of current assets to current liabilities. Overall, firms with liquidity shortages are likely to use more trade credit to overcome such situations (Boissay and Gropp 2007). Moreover, according to financing and pecking order theory, more solvent and liquid 
firms tend to rely less on trade credit due to their higher costs compared to bank loans (Ceustermans et al. 2017). Accordingly, we expect a negative Effect of both solvency and liquidity on trade credit.

We control for firm growth. This was measured by the difference between profit current year and profit of previous year; divided by profit of previous year (Lin and Qiao 2020). We believe that the more it is the more is the need to finance new investments (Lin and Qiao 2020; Van den Bogaerd and Aerts 2014). Accordingly, they rely on an external source of finance particularly trade credit. We expect to have a positive coefficient.

Following prior research, firms with an inventory ratio will undoubtedly have more purchases and hence, they will use more trade credit (Elliehausen and Wolken 1993). We therefore control for inventory ratio. The inventory ratio is measured by the ratio of inventory to total assets. We expect to have a positive association between trade credit and inventory ratio.

Finally, we included accounts receivable as a control variable. It is measured by the ratio of accounts receivable to total assets. We expect a positive coefficient with trade credit since companies are likely to compensate accounts receivable with accounts payables (Paul and Wilson 2007).

\subsection{Research Model}

$$
\begin{aligned}
\text { TC } i, t= & \alpha 0+\beta 1 \text { CRDi }, t+\beta 2 \text { AGEi, } t+\beta 3 \text { SIZEi, } t+\beta 4 \text { TQi }, t+\beta 5 \text { SOLVEi }, t+ \\
& \beta 6 \text { LIQUIi, } t+\beta 7 \text { GROWTH } i, t+\beta 8 \text { INVEN } i, t+\beta 9 A R i, t+\epsilon
\end{aligned}
$$

where:

$\alpha=$ the intercept.

$\beta 1, \ldots, \beta 9=$ Regression coefficients.

$\varepsilon=$ Error term.

The following Table 2 presents variables' description:

Table 2. Variables' description.

\begin{tabular}{ccc}
\hline Variable & Symbol & Description \\
\hline Trade credit & TC & Accounts payable/total assets \\
Corporate Risk disclosure & CRD & Risk disclosure index as described in “Appendix A" \\
Firm age & AGE & Natural logarithm of the number of years since the incorporation of the company \\
Firm size & SIZE & Natural logarithm of total assets at the end of the year \\
Profitability & TQ & (Market value + total debts)/total assets \\
Inventory & INVEN & Inventory/total assets \\
Solvency & SOLVE & Equity/total assets \\
Liquidity & LIQUI & Current assets/current liabilities \\
Growth & GROWTH & (Profit current year (N)- profit of $(\mathrm{N}-1)$ ) $/$ profit $(\mathrm{N}-1)$ \\
Accounts receivable & AR & Accounts receivable/total assets \\
\hline
\end{tabular}

\section{Empirical Analysis and Robustness Check}

\subsection{Descriptive Analysis}

Table 3 reports our descriptive analysis. On average, during 2008-2013, the accounts payable-to-total asset ratio (TC) is about 0.138 . This is consistent with prior research (Ceustermans et al. 2017). The CRD is on average about 5.424. Accordingly, there is a low level of risk disclosure for Tunisian-listed companies. This is in line with previous studies on risk disclosure in emerging markets particularly in Tunisia (e.g., Haj-Salem et al. 2020). The average age of the companies in our sample is about 44 years (the natural logarithm of age is on average 3.790). Hence, overall, our sample is characterized by old firms. The mean value of logged total assets (SIZE) is 7.96. We can consider that the companies in our sample are medium-sized with approximately a total asset of 2864.07 TND. Furthermore, the market value of the companies (TQ) generates a mean of 1.660 and a mean of inventory (INVEN) ratio of $20.94 \%$. Regarding, solvency (SOLVE) and liquidity (LIQUI) ratios they 
report a mean of $47.69 \%$ and $217 \%$, respectively. Moreover, the growth ratio (GROW) is about $-13.72 \%$. Hence, Tunisian firms during 2008-2013 are facing a period of crisis that negatively influence firms' profitability and growth. Finally, accounts receivables make up an average of $17.810 \%$ of total assets.

Table 3. Descriptive analysis.

\begin{tabular}{cccccc}
\hline Variable & Obs & Mean & Std. Dev. & Min & Max \\
\hline TC & 146 & 0.1382692 & 0.1033652 & 0.0019 & 0.399 \\
CRD & 146 & 5.424658 & 3.062196 & 1 & 13 \\
AGE & 146 & 3.790805 & 0.4049906 & 2.5649 & 4.5643 \\
SIZE & 146 & 7.965512 & 0.4891449 & 7.0494 & 9.2242 \\
TQ & 146 & 1.660255 & 0.9608301 & 0.3574 & 5.8751 \\
INVEN & 140 & 0.2094964 & 0.1964394 & 0.0012 & 0.9219 \\
SOLVE & 146 & 0.4769548 & 0.379287 & -1.2082 & 0.993 \\
LIQUI & 146 & 2.170023 & 1.751522 & 0.3241 & 9.3967 \\
GROW & 146 & -0.1372239 & 6.637974 & -42.1083 & 34.5245 \\
AR & 146 & 0.1781027 & 0.1522464 & 0 & 0.5895 \\
\hline
\end{tabular}

Note: This table presents the descriptive statistics for our variables. All variables are defined in Table 2.

\subsection{Correlation Analysis}

Table 4 reports the Spearman correlation. The multicollinearity issue is checked using this matrix. No value is greater than 0.8 which confirms the non-existence of multicollinearity between variables. Furthermore, we addressed also multicollinearity by examining the variance inflation factors (VIF) which provides a VIF that does not exceed 10. This is presented in Table 5. Hence, the multicollinearity assumption was not breached.

Table 4. Correlations matrix.

\begin{tabular}{|c|c|c|c|c|c|c|c|c|c|c|}
\hline Variables & (1) & (2) & (3) & (4) & (5) & (6) & (7) & (8) & (9) & (10) \\
\hline (1) TC & 1.00 & & & & & & & & & \\
\hline (2) CRD & 0.05 & 1.00 & & & & & & & & \\
\hline (3) AGE & 0.09 & -0.08 & 1.00 & & & & & & & \\
\hline (4) SIZE & 0.01 & $0.17^{*}$ & $0.21 *$ & 1.00 & & & & & & \\
\hline (5) TQ & 0.06 & -0.27 * & 0.34 * & 0.02 & 1.00 & & & & & \\
\hline (6) INVEN & 0.03 & -0.11 & 0.00 & $-0.22 *$ & -0.08 & 1.00 & & & & \\
\hline (7) SOLVE & $-0.20 *$ & -0.24 * & 0.17 * & -0.12 & -0.01 & -0.09 & 1.00 & & & \\
\hline (8) LIQUI & -0.34 * & -0.15 & 0.01 & $-0.25^{*}$ & 0.03 & 0.17 & $0.57 *$ & 1.00 & & \\
\hline (9) GROWTH & -0.04 & 0.06 & 0.10 & 0.20 * & 0.01 & 0.00 & 0.06 & 0.06 & 1.00 & \\
\hline (10) AR & 0.24 * & 0.02 & -0.09 & $-0.32 *$ & -0.01 & -0.11 & -0.05 & -0.04 & $-0.17^{*}$ & 1.00 \\
\hline
\end{tabular}

Note: This table demonstrates the correlation matrix among variables utilized in the study's model. All variables are defined in Table 2. * demonstrate the levels of significance at 0.10 .

Table 5. Variance inflation factors (VIF).

\begin{tabular}{ccc}
\hline Variable & VIF & $\mathbf{1 / V I F}$ \\
\hline SOLVE & 1.98 & 0.504221 \\
LIQUI & 1.93 & 0.519378 \\
SIZE & 1.63 & 0.614319 \\
TQ & 1.33 & 0.750454 \\
AGE & 1.33 & 0.754157 \\
INVEN & 1.25 & 0.802816 \\
CRD & 1.22 & 0.821464 \\
AR & 1.12 & 0.892728 \\
GROW & 1.12 & 0.894476 \\
\hline Mean VIF & 1.43 & \\
\hline All variables are defined in Table 2. & &
\end{tabular}

All variables are defined in Table 2. 


\subsection{Regression Results}

We conducted a panel data approach. Before starting, we checked for omitted variables. This was done through the Ramsey test. We found an F $(3,127)=0.85$ and Prob > $\mathrm{F}=0.4665$. Hence, no omitted variables are revealed for our model. First, we generated the specification panel test to judge the homogeneity or heterogeneity among individuals. The Chow test showed a prob $>\mathrm{F}=0.000$. Accordingly, the null hypothesis of homogeneity is rejected. Secondly, we check for the individual effect. For that, we generate respectively, a fixed-effect model, and a random-effect model. The comparison between the two models, by the Hausman test, we found that the random effect is the most suitable model since chi2 $(8)=13.73$ and Prob $>$ chi $2=0.0890$. Hence, the interpretations are according to the findings of the random effect regression. Moreover, we check for homoscedasticity. The Breusch and Pagan Lagrangian multiplier test for random effects was generated. Consequently, the findings of this test report that chibar2 $(01)=125.31$ and Prob $>$ chibar2 $=0.0000$. This indicates, that there is a heteroscedasticity problem. This issue has been corrected to avoid unbiased results following the method of White (1980). Furthermore, the autocorrelation between residuals was checked following the test of the Wooldridge (2002). According to the F statistics displayed through this test, the null hypothesis of autocorrelation is rejected $(\mathrm{F}(1,25)=1.118$; Prob $>\mathrm{F}=0.3005)$.

Table 6 reports the findings of the random effect model. The results show a positive and significant association between CRD and trade credit. This suggests that firms with higher risk disclosure receive more trade financing from suppliers. The results are consistent with H1. The results could be explained according to signaling and agency theory. Indeed, the CRD decrease information asymmetry. Consequently, suppliers may avoid customers' risk payment default, better assess the firm wealth, and are likely to provide more trade credit (Ceustermans et al. 2017). Moreover, retaining information may send a bad signal for suppliers and they will consider it as withholding the worst possible information which may refrain from lending decisions (Spence 1973). Our findings are consistent with previous studies (Ceustermans et al. 2017; Xu et al. 2020).

Table 6. Results.

\begin{tabular}{ccccccc}
\hline TC & Coef. & Std. Err. & $\mathbf{z}$ & $\mathbf{P}>\mathbf{z}$ & [95\% Conf. & Interval] \\
\hline CRD & 0.002461 & 0.0013731 & 1.79 & $0.073^{*}$ & -0.0002303 & 0.0051523 \\
AGE & 0.0295114 & 0.0146549 & 2.01 & $0.044^{* *}$ & 0.0007883 & 0.0582346 \\
SIZE & 0.0250873 & 0.0108888 & 2.30 & $0.021^{* *}$ & 0.0037457 & 0.0464289 \\
TQ & -0.0078299 & 0.0056521 & -1.39 & 0.166 & -0.0189078 & 0.0032479 \\
INVEN & 0.0771459 & 0.0221102 & 3.49 & $0.000^{* * *}$ & 0.0338108 & 0.120481 \\
SOLVE & 0.0533021 & 0.0163949 & 3.25 & $0.001^{* * *}$ & 0.0211687 & 0.0854355 \\
LIQUI & -0.0218254 & 0.003589 & -6.08 & $0.000^{* * *}$ & -0.0288596 & -0.0147912 \\
GROW & -0.0002238 & 0.0007146 & -0.31 & 0.754 & -0.0016244 & 0.0011768 \\
AR & 0.1756127 & 0.0317851 & 5.52 & $0.000^{* * *}$ & 0.113315 & 0.2379104 \\
_cons & -0.203238 & 0.094263 & -2.16 & 0.031 & -0.3879901 & -0.0184858 \\
\hline
\end{tabular}

Note: This table illustrates the findings of the random-effect model after dealing with the heteroscedasticity problem. ${ }^{* * * * *}$, and ${ }^{*}$ demonstrate the levels of significance at: $0.01,0.05$, and 0.10 , respectively.

Looking at the coefficients on the control variables, we find that respectively, age, size, inventory, solvency, and accounts receivable are positively and significantly associated with trade credit. Indeed, larger firms are more likely to have access easily to trade credit (Ceustermans et al. 2017). This is in line with our expectations. However, we expected that there is a negative association between solvency and trade credit since, according to financing and pecking order theory, more solvent and liquid firms tend to rely less on trade credit. Additionally, we find a negative and significant association between trade credit and liquidity, which suggests that firms with a lower liquidity ratio use more trade credit. No association was revealed between profitability, growth, and trade credit. 


\subsection{Robustness Check}

It is crucial to check for the robustness of the empirical findings to ensure their validity. According to previous studies (Cooke 1998), the transformation allows solving several issues such as non-normal distribution, non-linearity between dependent and independent variables, etc. Hence a log transformation for the dependent variable is performed. Table 7 provides the findings of the random effect regression and those after, both, log transformation and using another measure for trade credit. The similarity of the results allows us to conclude about their validity.

Table 7. Robustness check.

\begin{tabular}{|c|c|c|c|}
\hline \multicolumn{3}{|c|}{ Robustness Check } & \\
\hline $\begin{array}{l}\text { Different Measure for the } \\
\text { Dependent Variable }\end{array}$ & $\begin{array}{c}\text { Log } \\
\text { Transformation }\end{array}$ & Results & \\
\hline $\begin{array}{c}0.014^{* * *} \\
(4.46)\end{array}$ & $\begin{array}{l}0.020 * \\
(1.82)\end{array}$ & $\begin{array}{l}0.002 * \\
(1.79)\end{array}$ & CRD \\
\hline $0.091^{* * *}$ & $0.266^{* *}$ & 0.030 ** & AGE \\
\hline$(2.99)$ & $(2.39)$ & $(2.01)$ & \\
\hline-0.023 & 0.040 & $0.025^{* *}$ & SIZE \\
\hline$(-0.74)$ & $(0.38)$ & $(2.30)$ & \\
\hline-0.017 & -0.047 & -0.008 & TQ \\
\hline$(-1.63)$ & $(-1.31)$ & $(-1.39)$ & \\
\hline-0.012 & $0.803^{* * *}$ & $0.077^{* * *}$ & INVEN \\
\hline$(-0.23)$ & (3.94) & $(3.49)$ & \\
\hline $0.212^{* * *}$ & $0.436^{* * *}$ & $0.053^{* * *}$ & SOLV \\
\hline$(9.86)$ & $(3.78)$ & $(3.25)$ & \\
\hline-0.007 & $-0.250^{* * *}$ & $-0.022^{* * *}$ & LIQUI \\
\hline$(-0.85)$ & $(-7.46)$ & $(-6.08)$ & \\
\hline 0.000 & -0.001 & -0.000 & GROW \\
\hline$(0.10)$ & $(-0.16)$ & $(-0.31)$ & \\
\hline $0.229^{* * *}$ & $1.688^{* * *}$ & $0.176^{* * *}$ & AR \\
\hline$(2.92)$ & $(6.45)$ & $(5.52)$ & \\
\hline-0.028 & $-3.694^{* * *}$ & $-0.203^{* *}$ & _cons \\
\hline$(-0.10)$ & $(-4.00)$ & $(-2.16)$ & \\
\hline 140 & 140 & 140 & $\mathrm{~N}$ \\
\hline
\end{tabular}

\section{Conclusions}

We investigate the impact of risk disclosure on trade credit for Tunisian listed companies during 2008-2013. We find that risk disclosure determines the trade credit provided by suppliers to their customers. Hence, risk disclosure mitigates information asymmetry and this leads to a positive association with the obtained trade credit. Moreover, risk disclosure sends signals to suppliers helping them to assess adequately the firm risk situation and to avoid any misinterpretation or to imagine the worst situation. This helps suppliers to extend more trade credit. Our results are robust after using on the one hand a log transformation and on the other hand another measure of trade credit.

We choose Tunisia, as an example of the emerging economies, to undertake our analysis and hence we are filling an important research gap in the literature. In addition, examining the impact of risk disclosure on trade credit is a novel feature of our paper.

Our findings have several implications for different stakeholders. First, our study showed that the risk information in annual reports is important for a firm since it helps for having more trade credit which is an important source of financing. Accordingly, managers and the board of directors have to pay attention to the communication of more risk information when preparing annual reports to beneficiate from more trade credit.

Second, this study may be relevant to regulators to emphasize the importance of risk disclosures since it will have a positive impact on economic growth. Finally, we may 
consider the risk disclosure relevant to suppliers who are likely to grant more trade credit to their customers.

Our study is subject to a number of limitations. The first limitation is the relatively small sample. Nevertheless, this is due to the unavailability of annual reports in addition to the manual data collection. However, our sample is representative since it is composed most of non-financial-listed companies. The second limitation is inherent to the subjectivity of manual content analysis. However, we followed previous literature to assess the reliability and validity of our scores. Further research could investigate this association for other research contexts. Further research could also investigate the impact of governance mechanisms on the disclosure-trade credit relationship.

Author Contributions: Conceptualization, I.H.-S. and K.H.; methodology, K.H.; software, I.H.-S.; validation, I.H.-S., K.H.; formal analysis, I.H.-S.; investigation, I.H.-S.; resources, I.H.-S.; data curation, I.H.-S.; writing—original draft preparation, I.H.-S.; writing—review and editing, K.H.; visualization, I.H.-S.; supervision, K.H. All authors have read and agreed to the published version of the manuscript.

Funding: This research received no external funding.

Institutional Review Board Statement: Not applicable.

Informed Consent Statement: Not applicable.

Data Availability Statement: Data available on request due to restrictions.

Acknowledgments: The authors would like to thank the editor and three anonymous referees for helpful comments on this research.

Conflicts of Interest: The authors declare no conflict of interest.

\section{Appendix A}

Risk disclosure level index adopted from Haj-Salem et al. (2020). *: Items added after reading annual reports.

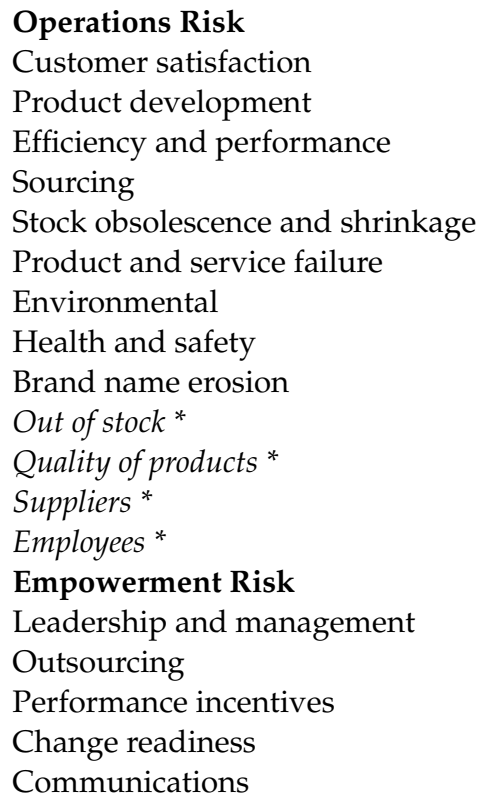




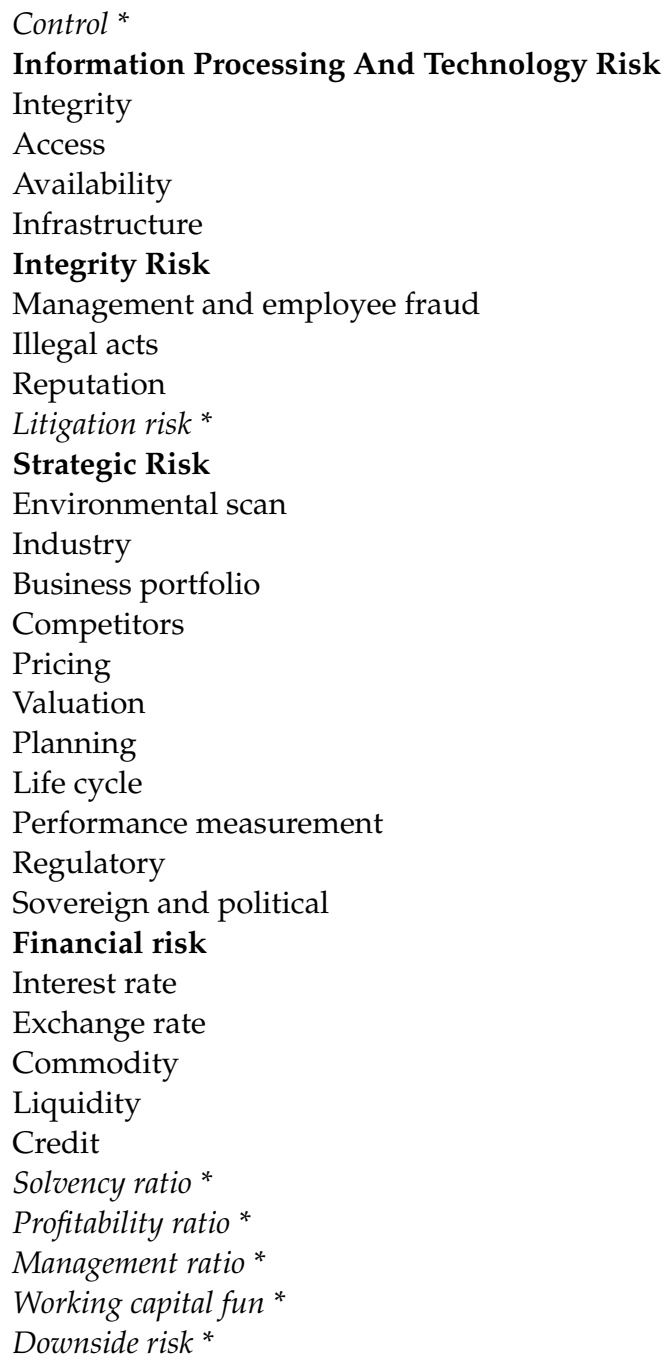

\section{References}

Abraham, Santhosh, and Paul Cox. 2007. Analysing the determinants of narrative risk information in UK FTSE 100 annual reports. The British Accounting Review 39: 227-48. [CrossRef]

Alkurdi, Amneh, Khaled Hussainey, Yasean Tahat, and Mohammad Aladwan. 2019. The impact of corporate governance on risk disclosure: Jordanian evidence. Academy of Accounting and Financial Studies Journal 23: 1-16.

Allini, Alessandra, Francesca Manes Rossi, and Khaled Hussainey. 2015. The board's role in risk disclosure: An exploratory study of Italian listed state-owned enterprises. Public Money \& Management 36: 113-20. [CrossRef]

Al-Maghzom, Abdullah, Khaled Hussainey, and Doaa A. Aly. 2016. Corporate governance and risk disclosure: Evidence from Saudi Arabia. Corporate Ownership and Control 13: 145-166. [CrossRef]

Al-Shammari, Bader. 2014. Kuwait corporate characteristics and level of risk disclosure: A content analysis approach. Journal of Contemporary Issues in Business Research 3: 128-53.

Alzead, Ramzi, and Khaled Hussainey. 2017. Risk disclosure practice in Saudi non-financial listed companies. Corporate Ownership and Control 14: 262-75. [CrossRef]

Amran, Azlan, Abdul Manaf Rosli Bin, and Bin Che Haat Mohd Hassan. 2008. Risk reporting. Managerial Auditing Journal $24:$ 39-57. [CrossRef]

Andrieu, Guillaume, Raffaele Staglianò, and Peter van der Zwan. 2017. Bank debt and trade credit for SMEs in Europe: Firm-, industry-, and country-level determinants. Small Business Economics 51: 245-64. [CrossRef]

Arruñada, Benito. 2010. Mandatory accounting disclosure by small private companies. European Journal of Law and Economics 32: 377-413. [CrossRef]

Banya, Roland Mwesigwa, and Nicholas Biekpe. 2017. Bank competition and economic growth. Journal of Economic Studies 44: 245-65. [CrossRef]

Bazzana, Flavio, Giacomo De Laurentis, Raoul Pisani, and Renata Trinca Colonel. 2019. Can domestic trade credit insurance contracts be effective collateral for banks? A quantitative study of the Italian market. The European Journal of Finance 26: 1239-52. [CrossRef] 
Beretta, Sergio, and Saverio Bozzolan. 2004. A framework for the analysis of firm risk communication. The International Journal of Accounting 39: 265-88. [CrossRef]

Boissay, Frédéric, and Reint Gropp. 2007. Trade Credit Defaults and Liquidity Provision by Firms. ECB Working Paper No. 753. Frankfurt: European Central Bank.

Brown, Philip, Wendy Beekes, and Peter Verhoeven. 2011. Corporate governance, accounting and finance: A review. Accounting $\mathcal{E}$ Finance 51: 96-172. [CrossRef]

Bufarwa, Idris M., Ahmed A. Elamer, Collins G. Ntim, and Aws AlHares. 2020. Gender diversity, corporate governance and financial risk disclosure in the UK. International Journal of Law and Management 62: 521-38. [CrossRef]

Ceustermans, Stefanie, Diane Breesch, and Joël Branson. 2017. Voluntary Disclosure of Sales and the Extent of Trade Credit in Small Private Companies. Accounting in Europe 14: 388-406. [CrossRef]

Chen, Deqiu, Ming Liu, Tao Ma, and Xiumin Martin. 2017. Accounting quality and trade credit. Accounting Horizons 31: 69-83. [CrossRef]

Chen, Shenglan, Hui Ma, and Qiang Wu. 2019. Bank credit and trade credit: Evidence from natural experiments. Journal of Banking E Finance 108: 105616. [CrossRef]

Cheng, Nam Sang, and Richard Pike. 2003. The trade credit decision: Evidence of UK firms. Managerial and Decision Economics 24: 419-38. [CrossRef]

Cooke, Terry E. 1998. Regression analysis in accounting disclosure studies. Accounting and Business Research 28: 209-24. [CrossRef]

Deloof, Marc, and Maurizio La Rocca. 2015. Local financial development and the trade credit policy of Italian SMEs. Small Business Economics 44: 905-24. [CrossRef]

Deumes, R. 2008. Corporate Risk Reporting: A Content Analysis of Narrative Risk Disclosures in Prospectuses. Journal of Business Communication 45: 120-57. [CrossRef]

Diamond, Douglas W., and Robert E. Verrecchia. 1991. Disclosure, liquidity, and the cost of capital. The journal of Finance 46: 1325-59. [CrossRef]

Elliehausen, Gregory E., and John D. Wolken. 1993. The demand for trade credit: An investigation of motives for trade credit use by small businesses. Federal Reserve Bulletin 79: 929.

Elshandidy, Tamer, and Lorenzo Neri. 2015. Corporate Governance, Risk Disclosure Practices, and Market Liquidity: Comparative Evidence from the UK and Italy. Corporate Governance: An International Review 23: 331-56. [CrossRef]

Elshandidy, Tamer, and Philip J. Shrives. 2016. Environmental Incentives for and Usefulness of Textual Risk Reporting: Evidence from Germany. The International Journal of Accounting 51: 464-86. [CrossRef]

Elshandidy, Tamer, Ian Fraser, and Khaled Hussainey. 2013. Aggregated, voluntary, and mandatory risk disclosure incentives: Evidence from UK FTSE all-share companies. International Review of Financial Analysis 30: 320-33. [CrossRef]

Elzahar, Hany, and Khaled Hussainey. 2012. Determinants of narrative risk disclosures in UK interim reports. The Journal of Risk Finance 13: 133-47. [CrossRef]

Fama, Eugene F., and Michael C. Jensen. 1983. Agency problems and residual claims. The Journal of Law and Economics 26: 327-49. [CrossRef]

Fisman, Raymond. 2001. Trade credit and productive efficiency in developing countries. World Development 29: 311-21. [CrossRef]

Fowowe, Babajide. 2017. Access to finance and firm performance: Evidence from African countries. Review of Development Finance 7: 6-17. [CrossRef]

Fox, John. 2015. Applied Regression Analysis and Generalized Linear Models. Thousand Oaks: Sage Publications.

García-Teruel, Pedro Juan, and Pedro Martínez-Solano. 2007. Effects of working capital management on SME profitability. International Journal of Managerial Finance 3: 164-77. [CrossRef]

Giannetti, Mariassunta, Mike Burkart, and Tore Ellingsen. 2011. What You Sell Is What You Lend? Explaining Trade Credit Contracts. Review of Financial Studies 24: 1261-98. [CrossRef]

Haj-Salem, Issal, Salma Damak Ayadi, and Khaled Hussainey. 2019. Corporate governance and risk disclosure quality: Tunisian evidence. Journal of Accounting in Emerging Economies 9: 567-602. [CrossRef]

Haj-Salem, Issal, Salma Damak Ayadi, and Khaled Hussainey. 2020. The joint effect of corporate risk disclosure and corporate governance on firm value. International Journal of Disclosure and Governance 17: 123-40. [CrossRef]

Huyghebaert, Nancy, Linda Van de Gucht, and Cynthia Van Hulle. 2007. The Choice between Bank Debt and Trace Credit in Business Start-ups. Small Business Economics 29: 435-52. [CrossRef]

Islam, Mohammad Nazrul, and Clark M. Wheatley. 2020. Impact of Climate Risk on Firms' Use of Trade Credit: International Evidence. The International Trade Journal 35: 40-59. [CrossRef]

White, Halbert. 1980. A heteroskedasticity-consistent covariance matrix estimator and a direct test for heteroskedasticity. Econometrica 48: 817-838. [CrossRef]

Jensen, Michael C., and William H. Meckling. 1976. Theory of the firm: Managerial behavior, agency costs and ownership structure. Journal of Financial Economics 3: 305-60. [CrossRef]

Khlif, Hichem, and Khaled Hussainey. 2016. The association between risk disclosure and firm characteristics: A meta-analysis. Journal of Risk Research 19: 181-211. [CrossRef]

Krippendorff, Klaus. 2004. Reliability in content analysis: Some common misconceptions and recommendations. Human Communication Research 30: 411-33. [CrossRef] 
Lin, Qiang, and Beibei Qiao. 2020. The relationship between trade credit and bank loans under economic fluctuations-based on the perspective of the supply chain. Applied Economics 53: 688-702. [CrossRef]

Linsley, Philip M., Phillip J. Shrives, and Mandy Crumpton. 2006. Risk disclosure: An exploratory study of UK and Canadian banks. Journal of Banking Regulation 7: 268-82. [CrossRef]

Long, Michael S., Ileen B. Malitz, and S. Abraham Ravid. 1993. Trade credit, quality guarantees, and product marketability. Financial Management 22: 117-127. [CrossRef]

Marston, Claire L., and Philip J. Shrives. 1991. The use of disclosure indices in accounting research: A review article. The British Accounting Review 23: 195-210. [CrossRef]

Miihkinen, Antti. 2012. What Drives Quality of Firm Risk Disclosure? The International Journal of Accounting 47: 437-68. [CrossRef]

Miihkinen, Antti. 2013. The usefulness of firm risk disclosures under different firm riskiness, investor-interest, and market conditions: New evidence from Finland. Advances in Accounting 29: 312-31. [CrossRef]

Moumen, Néjia, Hakim Ben Othman, and Khaled Hussainey. 2015. The value relevance of risk disclosure in annual reports: Evidence from MENA emerging markets. Research in International Business and Finance 34: 177-204. [CrossRef]

Nahar, Shamsun, Mohammad Istiaq Azim, and Md Moazzem Hossain. 2020. Risk disclosure and risk governance characteristics: Evidence from a developing economy. International Journal of Accounting $\mathcal{E}$ Information Management 28: 577-605. [CrossRef]

Pattnaik, Debidutta, Mohammad Kabir Hassan, Satish Kumar, and Justin Paul. 2020. Trade credit research before and after the global financial crisis of 2008-A bibliometric overview. Research in International Business and Finance 54: 101287. [CrossRef]

Paul, Salima, and N. Wilson. 2007. The determinants of trade credit demand: Survey evidence and empirical analysis. Journal of Accounting, Business and Management 14: 96-116.

Petersen, Mitchell A., and Raghuram G. Rajan. 1997. Trade credit: Theories and evidence. The Review of Financial Studies 10: 661-91. [CrossRef]

Schwartz, Robert A. 1974. An economic model of trade credit. Journal of Financial and Quantitative Analysis, 643-57. [CrossRef]

Smith, Janet Kiholm. 1987. Trade credit and informational asymmetry. The Journal of Finance 42: 863-72. [CrossRef]

Solomon, Jill F., Aris Solomon, Simon D. Norton, and Nathan L. Joseph. 2000. A Conceptual Framework for Corporate Risk Disclosure Emerging from the Agenda for Corporate Governance Reform. The British Accounting Review 32: 447-78. [CrossRef]

Spence, Michael. 1973. Job Market Signalling. The Quarterly Journal of Economics 87: 355-74. [CrossRef]

Van den Bogaerd, Machteld, and Walter Aerts. 2014. Media reputation of a firm and extent of trade credit supply. Corporate Reputation Review 17: 28-45. [CrossRef]

Van Horen, Neeltje. 2005. Trade Credit as a Competitiveness Tool: Evidence from Developing Countries. Available online: https: //mpra.ub.uni-muenchen.de/2792/1/MPRA_paper_2792.pdf (accessed on 1 January 2021).

Wooldridge, Jeffrey. 2002. Econometrics of cross section and panel data. Cambridge, MA: MIT Press, 2002a). "Inverse Probability Weighted M-Estimators for Sample Selection, Attrition and Stratification". Portuguese Economic Journal 1: 117-39. [CrossRef]

Xu, Hongkang, Trung H. Pham, and Mai Dao. 2020. Annual report readability and trade credit. Review of Accounting and Finance 19: 363-85. [CrossRef]

Yohn, Teri Lombardi, and Kristian D. Allee. 2009. The Demand for Financial Statements in an Unregulated Environment: An Examination of the Production and Use of Financial Statements by Privately Held Small Businesses. The Accounting Review 84: 1-25. [CrossRef] 